\title{
Arthroscopic findings and treatment of maisonneuve fracture complex
}

\author{
Lukas Fraissler $^{1 *}$, Georg Mattiassich ${ }^{1,2}$, Lars Brunnader ${ }^{1}$ and Lukas A. Holzer ${ }^{1,3}$
}

\begin{abstract}
Background: The Maisonneuve fracture complex (MFC) is a well-known lower leg injury. However, the optimal treatment is still not clear and there is limited data on concomitant injuries of cartilage. Therefore, the aim of our study was to report the incidence of incidental cartilage injuries and their management in arthroscopic treatment of MFC.

Patients and methods: Between February 2018 and February 2021 all patients presenting with MFC in our department were treated with diagnostic ankle arthroscopy and percutaneous syndesmotic screw or suture-endobutton fixation. In case of instable cartilage, it was debrided and according to the International Consensus Meeting on Cartilage Repair of the Ankle, in grade IV lesions $<10 \mathrm{~mm}$ or $<100 \mathrm{~mm}^{2}$ area the subchondral bone was microfractured.
\end{abstract}

Results: Eighteen patients, 16 male and two female, with a mean age of 48.1 years, were included. In all cases, instability of the distal tibiofibular articulation was confirmed arthroscopically. Injuries of the cartilage were found in $56 \%$ of the cases and in $31 \%$ of the patients surgical intervention was required. In three talar and one tibial lesion additional arthroscopic bone marrow stimulation with microfracture of the subchondral bone was performed.

Conclusions: Ankle arthroscopy is a helpful method to guide fibular reduction and to detect and address associated cartilage injuries. Due to the high rate of chondral lesions, addressing these arthroscopically may contribute to better postoperative results.

Level of evidence: IV

Keywords: Maisonneuve fracture, Tibio-fibular instability, Syndesmotic rupture, Ankle arthroscopy, Osteochondral lesion, Cartilage lesion

\section{Introduction}

"La fracture du péroné", or better known as Maisonneuve fracture complex (MFC) was first described by the French surgeon Jacques Gilles Maisonneuve in 1840 [1]. The injury typically consists of a fracture of the proximal fibula with disruption of the distal tibiofibular syndesmosis and a deltoid rupture or medial malleolus fracture.

The mechanism of the injury was described by Pankovich as a strong external rotation force with the foot in

*Correspondence: mail@dr-fraissler.at

1 Department of Orthopedic Surgery, Klinik Diakonissen Schladming, Salzburger Strasse 777, 8970 Schladming, Austria

Full list of author information is available at the end of the article slight supination and in neutral or slight pronation in later stages [2].

Regarding therapy, some authors reported of nonoperative treatment: Pankovich [2] treated the MFC nonoperatively in cases without rupture of the deltoid ligament, interosseous ligaments, or medial malleolus fracture and Merrill [3] suggested that these are often more stable than generally assumed. According to the Lauge-Hansen classification, this could be possible, but sometimes it is difficult to differentiate between partially and total ruptured syndesmotic ligaments preoperatively. Therefore, MFC should be assumed as an unstable injury, and most authors recommend operative treatment [4-9]. Stufkens [9] defined in their review of literature recommendations original author(s) and the source, provide a link to the Creative Commons licence, and indicate if changes were made. The images or other third party material in this article are included in the article's Creative Commons licence, unless indicated otherwise in a credit line to the material. If material is not included in the article's Creative Commons licence and your intended use is not permitted by statutory regulation or exceeds the permitted use, you will need to obtain permission directly from the copyright holder. To view a copy of this licence, visit http://creativecommons.org/licenses/by/4.0/. The Creative Commons Public Domain Dedication waiver (http://creativeco mmons.org/publicdomain/zero/1.0/) applies to the data made available in this article, unless otherwise stated in a credit line to the data. 
for treatment of Maisonneuve fractures: the medial malleolus should be fixated, the torn deltoid ligament need not be directly repaired, syndesmotic instability can be treated with one or two 3- or 4-cortical screws which can be placed percutaneously, and the proximal fibular fracture does not require direct internal fixation. However, the optimal operative management is not clear and various options are under debate.

Moreover, Hintermann [10] and Loren [11] reported of an incidence of cartilage lesions, including chondral defects and osteochondral lesions, in ankle fractures of $79.2 \%$, respectively $63 \%$. Yoshimura [8] reported that all patients with MFC, who underwent ankle arthroscopy, had cartilaginous damage to the medial section of the talar dome. Therefore, we started to treat patients with Maisonneuve fracture arthroscopically to detect and address concomitant injuries. The aim of this study was to retrospectively evaluate the incidence of cartilage injuries in these patients.

\section{Materials and methods}

Between February 2018 and February 2021 all 18 patients presenting with MFC, 16 men and two women, were treated consecutively with ankle arthroscopy in our department. The mean age at time of surgery was 48.1 years (range 23 to 74years). Eleven MFCs were sports related, six occurred as a result of an ankle sprain while walking, and one patient had a motorcycle accident (Table 1).

MFC was confirmed with radiographs of the ankle and knee. In 5 patients an additional CT-scan and in 3 patients an MRI of the ankle was performed.

Preoperatively, prophylactic antibiotics were given intravenously. All Arthroscopies were performed or attended by a national-board certified foot and ankle surgeon in spinal anaesthesia and tourniquet control. Therefore, patients were set in supine position, no ankle distractor was applied, and saline was injected to inflate the ankle joint. Routinely, a $4 \times 152.5 \mathrm{~mm} / 30^{\circ}$ arthroscope with standard anteromedial and anterolateral portals was used to access the ankle.

An anterior ankle examination, as described by Ferkel [12], was used to verify syndesmotic instability and to check for cartilage injuries. External rotation stress test was used to assess syndesmotic injury. Frank syndesmosis instability was defined by $\geq 2 \mathrm{~mm}$ displacement of the lateral malleolus (Fig. 1) [13]. Lesions of the cartilage were classified according to the International Cartilage Repair Society (ICRS) grading system [14].

Instable cartilage was debrided and, as recommended by the International Consensus Meeting on Cartilage Repair of the Ankle, in lesions $<10 \mathrm{~mm}$ or $<100 \mathrm{~mm}^{2}$ area subchondral bone was microfractured [15].
After addressing cartilage damage, avulsed ligaments and debris of the distal tibiofibular syndesmosis was resected with a $4 \mathrm{~mm}$ shaver to allow proper positioning of the fibula into the incisura. Closed reduction was performed with a sharp reduction clamp and controlled arthroscopically and fluoroscopically. Length to the fibula was restored and internal rotation as well as medial translation was assessed. Fixation of the fibula was either achieved with percutaneous placement of two tricortical $3.5 \mathrm{~mm}$ stainless steel screws or suture-endobuttons (TightRope $^{\circledR}$, Arthrex, Naples, FL).

Medial malleolar fractures were addressed with open reduction and screw fixation, whereas deltoid ligament disruptions were treated non-operatively in the context of postoperative immobilization with cast or walking boot. In cases of arthroscopy and microfracture of talus or tibia, or suture-endobutton fixation of the fibula, patients were instructed for partial weight-bearing $(15 \mathrm{~kg})$ for 6 weeks and with screw fixation only partial weightbearing $(15 \mathrm{~kg})$ for 2 weeks, followed by 4 weeks of full weight-bearing. According to our postoperative standard protocol syndesmosis screws were removed 6-8 weeks postoperative.

\section{Results}

In all 18 cases, a frank instability of the distal tibiofibular articulation was confirmed in intraoperative stress testing. Four patients had an arthroscopically confirmed disruption of the deltoid ligament and six patients a fracture of the medial malleolus. Furthermore, 11 patients had a radiologically approved additional posterior fracture of the distal tibia or tibial avulsion fracture of the posterior inferior tibiofibular ligament.

Traumatic lesions of the cartilage were found in 10 of 18 ankles (56\%). The medial aspect of the talar dome was involved in eight cases, while tibial articulation was affected in 2 patients. A wide range of different (osteo-) chondral lesions was seen intraoperatively (Figs. 2 and 3) and classified as shown in Table 1. With exception of the patient with the grade I talar lesion, additional operative treatment was needed in nine cartilage lesions. Therefore, all nine patients were treated with arthroscopical debridement of ruptured and loose cartilage. In three talar and one tibial lesion additional bone marrow stimulation with microfracture of the subchondral bone was necessary.

Postoperative treatment was performed according to our standard protocol with partial weight-bearing for 6 weeks or partial weight-bearing for 2 weeks, followed by 4 weeks of full weight-bearing and screw removal after 6 weeks.

Twelve patients were available for a short-term followup. Mean time to follow-up was 15 months (range 3 to 
Table 1 Patients characteristics, Surgical Intervention, Trauma mechanism, Findings

\begin{tabular}{|c|c|c|c|c|c|c|c|c|}
\hline Age [years] & Sex & Side & $\begin{array}{l}\text { Diagnosis (in } \\
\text { addition to } \\
\text { syndesmotic } \\
\text { instability) }\end{array}$ & $\begin{array}{l}\text { Localization of } \\
\text { chondral lesion }\end{array}$ & $\begin{array}{l}\text { Size } \\
{[\mathrm{mm}]}\end{array}$ & ICRS Grade & $\begin{array}{l}\text { Surgical Intervention } \\
\text { (in addition to ankle } \\
\text { arthroscopy) }\end{array}$ & Trauma \\
\hline 57 & Male & right & $\begin{array}{l}\text { Chondral lesion, medial } \\
\text { malleolus fracture, pos- } \\
\text { terior tibia fracture }\end{array}$ & Talus medial & $5 \times 5$ & IV & $\begin{array}{l}\text { Microfracture, } 2 x \text { tri- } \\
\text { cortical } 3.5 \mathrm{~mm} \text { stain- } \\
\text { less steel screws, ORIF } \\
\text { medial malleolus }\end{array}$ & Skiing \\
\hline 46 & Male & left & $\begin{array}{l}\text { Medial malleolus } \\
\text { fracture }\end{array}$ & & & & $\begin{array}{l}\text { Suture-endobutton, } \\
\text { ORIF medial malleolus }\end{array}$ & Motorcycle riding \\
\hline 24 & Female & right & Deltoid rupture & & & & Suture-endobutton & Bicycling \\
\hline 27 & Male & left & Chondral lesion & Tibia & $10 \times 4$ & IV & $\begin{array}{l}\text { Microfracture, } 2 x \\
\text { tricortical } 3.5 \mathrm{~mm} \\
\text { stainless steel screws }\end{array}$ & Ski mountaineering \\
\hline 52 & Male & left & $\begin{array}{l}\text { Chondral lesion, } \\
\text { medial malleolus frac- } \\
\text { ture, Chaput tubercle } \\
\text { fracture }\end{array}$ & Talus medial & $4 \times 4$ & IV & $\begin{array}{l}\text { Microfracture, percuta- } \\
\text { neous fixation medial } \\
\text { malleolus, } 2 x \text { tricortical } \\
3.5 \text { mm stainless steel } \\
\text { screws }\end{array}$ & Walking \\
\hline 74 & Male & right & $\begin{array}{l}\text { Medial malleolus } \\
\text { fracture, posterior tibia } \\
\text { fracture }\end{array}$ & & & & $\begin{array}{l}2 x \text { tricortical } 3.5 \mathrm{~mm} \\
\text { stainless steel screws }\end{array}$ & Cross-country skiing \\
\hline 41 & Male & left & $\begin{array}{l}\text { Chondral lesion, poste- } \\
\text { rior tibia fracture }\end{array}$ & Talus medial & $4 \times 4$ & I & $\begin{array}{l}2 x \text { tricortical } 3.5 \mathrm{~mm} \\
\text { stainless steel screws }\end{array}$ & Ski mountaineering \\
\hline 49 & Male & right & $\begin{array}{l}\text { Deltoid rupture, poste- } \\
\text { rior tibia fracture }\end{array}$ & & & & $\begin{array}{l}2 x \text { tricortical } 3.5 \mathrm{~mm} \\
\text { stainless steel screws }\end{array}$ & Martial Arts \\
\hline 55 & Male & right & $\begin{array}{l}\text { Chondral lesion, del- } \\
\text { toid rupture posterior } \\
\text { tibia fracture }\end{array}$ & Talus medial & $8 \times 6$ & IV & $\begin{array}{l}\text { Microfracture, } 2 x \\
\text { tricortical } 3.5 \mathrm{~mm} \\
\text { stainless steel screws, }\end{array}$ & Hiking \\
\hline 61 & Male & left & Deltoid rupture & & & & $\begin{array}{l}2 x \text { tricortical } 3.5 \mathrm{~mm} \\
\text { stainless steel screws }\end{array}$ & Hiking \\
\hline 23 & Male & left & $\begin{array}{l}\text { Medial malleolus } \\
\text { fracture, posterior tibia } \\
\text { fracture }\end{array}$ & & & & $\begin{array}{l}2 x \text { tricortical } 3.5 \mathrm{~mm} \\
\text { stainless steel screws }\end{array}$ & Walking \\
\hline 40 & Male & right & $\begin{array}{l}\text { Osteochondral lesion, } \\
\text { posterior tibia fracture }\end{array}$ & Tibia & N/A & IV & $\begin{array}{l}\text { Debridement of unsta- } \\
\text { ble cartilage/bone, } \\
\text { ORIF medial malleolus, } \\
\text { 2x tricortical } 3.5 \mathrm{~mm} \\
\text { stainless steel screws }\end{array}$ & Ski mountaineering \\
\hline 43 & Male & left & $\begin{array}{l}\text { Osteochondral lesion, } \\
\text { medial malleolus } \\
\text { fracture, posterior tibia } \\
\text { fracture }\end{array}$ & Tibia, Talus medial & $22 \times 4 \times 4,10 \times 5$ & $\begin{array}{l}\text { IV, } \\
\text { III }\end{array}$ & $\begin{array}{l}\text { Debridement of unsta- } \\
\text { ble cartilage/bone, } \\
\text { ORIF medial malleolus, } \\
2 x \text { tricortical } 3.5 \mathrm{~mm} \\
\text { stainless steel screws }\end{array}$ & Walking \\
\hline 33 & Male & left & $\begin{array}{l}\text { Deltoid rupture, poste- } \\
\text { rior tibia fracture }\end{array}$ & & & & $\begin{array}{l}2 x \text { tricortical } 3.5 \mathrm{~mm} \\
\text { stainless steel screws }\end{array}$ & Walking \\
\hline 69 & Male & right & $\begin{array}{l}\text { Chondral lesion, del- } \\
\text { toid rupture, posterior } \\
\text { tibia fracture }\end{array}$ & Talus medial & $10 \times 5$ & IV & $\begin{array}{l}\text { Microfracture, } 2 x \\
\text { tricortical } 3.5 \mathrm{~mm} \\
\text { stainless steel screws, }\end{array}$ & Walking \\
\hline 63 & Male & right & & & & & $\begin{array}{l}2 x \text { tricortical } 3.5 \mathrm{~mm} \\
\text { stainless steel screws }\end{array}$ & Hiking \\
\hline 40 & Male & right & & & & & $\begin{array}{l}2 x \text { tricortical } 3.5 \mathrm{~mm} \\
\text { stainless steel screws }\end{array}$ & Hiking \\
\hline 68 & Female & right & Chondral lesion & Talus medial & $3 \times 8$ & IV & $\begin{array}{l}\text { Debridement of unsta- } \\
\text { ble cartilage/bone, } \\
2 x \text { tricortical } 3.5 \mathrm{~mm} \\
\text { stainless steel screws }\end{array}$ & Walking \\
\hline
\end{tabular}




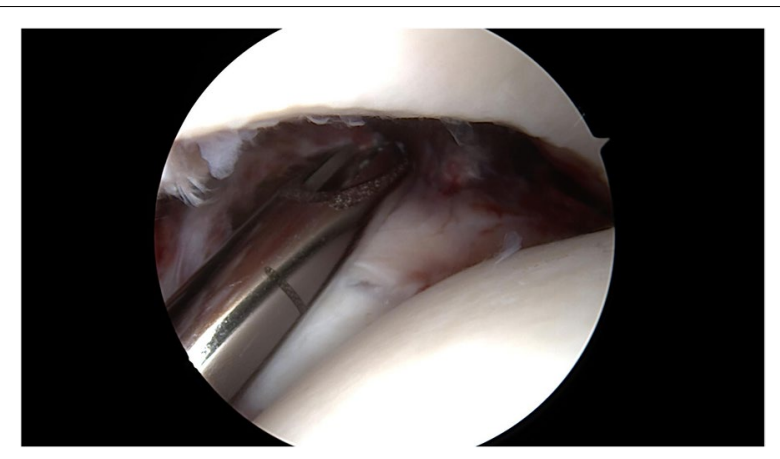

Fig. 1 Diastasis of the distal fibula was proven with a $4 \mathrm{~mm}$ shaver. In all cases an apparent syndesmosis instability of at least $4 \mathrm{~mm}$ was seen

27 months). No perioperative infections or wound complications occurred. After 10 months one patient needed revision surgery due to secondary syndesmosis and deltoid ligament diastasis and in one case of TightRope ${ }^{\circledR}$ fixation implant removal and arthroscopic scar debridement was necessary. None of the patients complained about secondary cartilage issues. At the time of last follow-up all patients were very satisfied or satisfied with the results.

\section{Discussion}

Treatment of MFC varies widely; traditional therapy consists of open or percutaneous techniques with restoration of the ankle mortise and syndesmosis screw fixation. Kalyani [16] reported in a review, including 61 patients in 4 studies, of excellent results in $47.54 \%$, good in $40.98 \%$, fair in $4.92 \%$ and poor in $6.55 \%$ as well as an ankle arthrosis rate of $16 \%$ after an follow-up period from 25.3 months to 6.4 years. Furthermore, a high rate of associated cartilage lesions in common ankle fractures of up to $79.2 \%$ $[10,11]$ and $100 \%$ in MFC [8] have been described. According to this data, a high rate of concomitant cartilage injuries is confirmed in our study. Therefore, ankle arthroscopy might be a favourable method to detect and subsequently treat associated injuries.

In general, the incidence of complications in ankle arthroscopy is low. Imade [17] reported of one patient with compartment syndrome following ankle arthroscopy after MFC. In our own patient collective, as well as in the report of Yoshimura [8], were no complications as a result of ankle arthroscopy found.

Furthermore, the mechanism of injury was supposed to be a strong external rotation force with the foot in slight supination and in neutral or slight pronation in later stages [2]. Based on the fact that there was no damage to the posterior malleolus in their patient collective, Yoshimura [8] concluded that there is a strong possibility that the MFC could be a pronation external rotation type fracture according to the Lauge-Hansen classification. In four of our patients MFC occurred in a ski boot while skiing; Fritschy [18] also reported of Maisonneuve injuries in professional skiers with rigid ski boots, in which pronation or supination is theoretically impossible. Therefore, the mechanism of injury and potentially associated intra-articular damage have to be thought about.

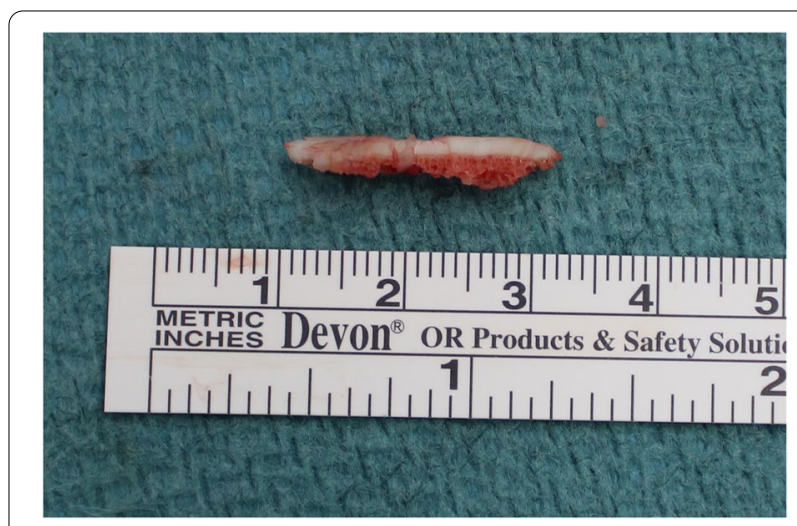

Fig. 3 In one patient a $22 \times 4 \times 4 \mathrm{~mm}$ osteochondral fragment of the anteromedial edge of the distal tibia had to be removed

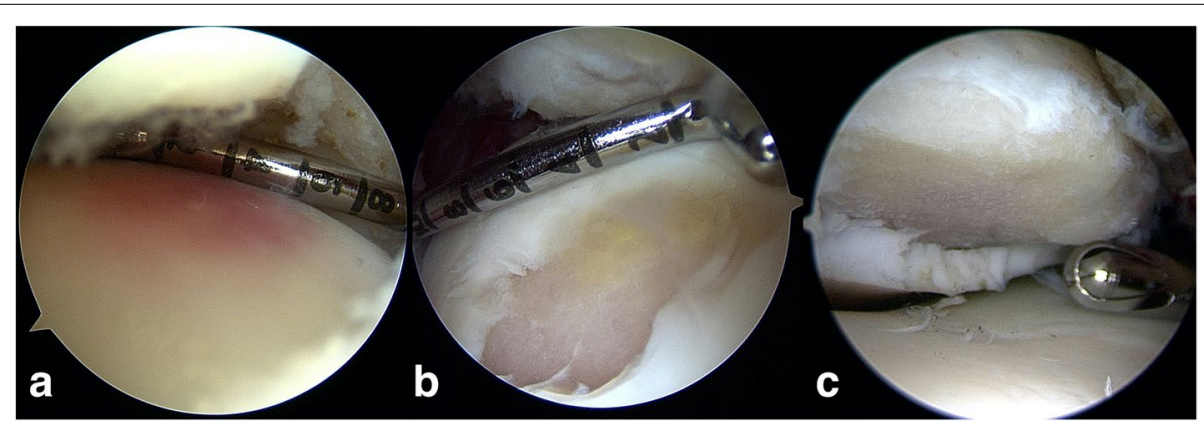

Fig. 2 A variety of (osteo-)chondral lesions were found arthroscopically: cartilage hematoma (a) as well as instable talar (b) and tibial (c) cartilage injuries, which were debrided and subchondral bone microfractured 
Regarding limitations of this study, the small and heterogenous patient collective has to be disclosed. Furthermore, there was no control group, a short follow-up time and no long-time results available. On the other hand, the strength of this paper represents the largest number of study participants with MFC who were treated arthroscopically in current literature and all patients were treated by a national-board certified foot and ankle surgeon.

\section{Conclusions}

Ankle arthroscopy is helpful to detect and treat cartilage lesions of talus and tibia in MFC, as well as to guide fibular reduction. To avoid secondary complications, we do not recommend using endobutton fixation for MFC and early screw removal. Furthermore, the long-term results of this technique compared to conventional open surgery need to be evaluated in a larger patient cohort. Nonetheless, due to the high rate of chondral lesions, addressing these arthroscopically may contribute to better postoperative results.

\section{Abbreviations \\ MFC: Maisonneuve fracture complex; ICRS: International Cartilage Repair Society.}

\section{Acknowledgements}

We are thankful for the research grant from the Paracelsus Medical University Salzburg, Austria, covering the publication fee.

\section{Authors' contributions}

Lukas Fraissler was responsible for conception and design, acquisition and interpretation of data and drafting the manuscript. Lukas A. Holzer and Georg Mattiassich have made substantial contributions to conception and design and helped revising it critically for important intellectual content. Lars Brunnader was responsible for ethics approval. All authors read and approved the final manuscript.

\section{Funding}

The authors received no financial support for the research, authorship. The publication fee of this article will be paid by the Paracelsus Medical University Salzburg, Austria.

\section{Availability of data and materials}

The datasets used and/or analysed during the current study are available from the corresponding author on reasonable request.

\section{Declarations}

\section{Ethics approval and consent to participate}

This publication was performed in accordance with the ethical standards laid down in the 1964 Declarations of Helsinki. Informed consent was obtained orally from all participants. The study design and oral informed consent procedure have been approved by the ethics committee of the Medical University Graz, Austria (reference number EK33-305 ex 20/21).

\section{Consent for publication}

All methods were carried out in accordance with relevant guidelines and regulations. Images are entirely unidentifiable and there are no details on individuals reported within the manuscript.

\section{Competing interests}

The authors have no competing interests to declare.

\section{Author details}

${ }^{1}$ Department of Orthopedic Surgery, Klinik Diakonissen Schladming, Salzburger Strasse 777, 8970 Schladming, Austria. ${ }^{2}$ Paracelsus Medical University Salzburg, Strubergasse 21, 5020 Salzburg, Austria. ${ }^{3}$ AUVA Trauma Center Klagenfurt am Wörthersee, Waidmannsdorfer Strasse 35, 9020 Klagenfurt am Wörthersee, Austria.

Received: 17 March 2021 Accepted: 11 September 2021

Published online: 24 September 2021

\section{References}

1. Maisonneuve M. Recherches sur la fracture du péroné. Arch Gen Med. 1840;7:165-87.

2. Pankovich AM. Maisonneuve fracture of the fibula. J Bone Joint Surg Am. 1976;58:337-42.

3. Merrill KD. The Maisonneuve fracture of the fibula. Clin Orthop Relat Res. 1993;(287):218-23.

4. del Castillo J, Geiderman JM. The Frenchman's fibular fracture (Maisonneuve fracture). J Am Coll Emerg Physicians. 1979;8:404-6.

5. Obeid EM, Amr M, Hirst P, Paul A. Percutaneous fixation of Maisonneuve and Maisonneuve-type fractures: a minimally invasive approach. Injury. 1998;29:619-22.

6. Babis GC, Papagelopoulos PJ, Tsarouchas J, Zoubos AB, Korres DS, Nikiforidis P. Operative treatment for Maisonneuve fracture of the proximal fibula. Orthopedics. 2000;23:687-90.

7. Sproule JA, Khalid M, O'Sullivan M, McCabe JP. Outcome after surgery for Maisonneuve fracture of the fibula. Injury. 2004;35:791-8.

8. Yoshimura I, Naito M, Kanazawa K, Takeyama A, Ida T. Arthroscopic findings in Maisonneuve fractures. J Orthop Sci. 2008;13:3-6.

9. Stufkens SA, van den Bekerom MPJ, Doornberg JN, van Dijk CN, Kloen P. Evidence-based treatment of Maisonneuve fractures. J Foot Ankle Surg. 2011:50:62-7.

10. Hintermann B, Regazzoni P, Lampert C, Stutz G, Gächter A. Arthroscopic findings in acute fractures of the ankle. J Bone Jt Surg. 2000;82:345-51.

11. Loren GJ, Ferkel RD. Arthroscopic assessment of occult intra-articular injury in acute ankle fractures. Arthrosc J Arthrosc Relat Surg. 2002:18:412-21.

12. Ferkel RD, Brown DS. Diagnostic arthroscopic examination. In: Ferkel RD, editor. Foot and ankle arthroscopy. 2nd ed. Philadelphia: Wolters Kluwer; 2017. p. 138-54.

13. Lui TH, Ip K, Chow HT. Comparison of radiologic and arthroscopic diagnoses of distal tibiofibular syndesmosis disruption in acute ankle fracture. Arthrosc J Arthrosc Relat Surg. 2005;21:1370.e1-7.

14. Brittberg M, Peterson L. Introduction of an articular cartilage classification. ICRS Newsletter 1998;1:5-8.

15. Hannon CP, Bayer S, Murawski CD, Canata GL, Clanton TO, Haverkamp D, et al. Debridement, curettage, and bone marrow stimulation: proceedings of the international consensus meeting on cartilage repair of the ankle. Foot Ankle Int. 2018;39(1_suppl):16S-22S.

16. Kalyani BS, Roberts CS, Giannoudis PV. The Maisonneuve injury: a comprehensive review. Orthopedics. 2010;33:190-5.

17. Imade S, Takao M, Miyamoto W, Nishi H, Uchio Y. Leg anterior compartment syndrome following ankle arthroscopy after Maisonneuve fracture. Arthrosc J Arthrosc Relat Surg. 2009;25:215-8.

18. Fritschy D. Une lésion rare de la cheville chez les skieurs de compétition [A rare injury of the ankle in competition skiiers]. Schweiz Z Med Traumatol. 1994;(1):13-6.

\section{Publisher's Note}

Springer Nature remains neutral with regard to jurisdictional claims in published maps and institutional affiliations. 